\title{
Kalio hidrokarbonato poveikis žaliosios šerytės atsparumui užmirkimo sąlygomis
}

\author{
Rimanta Vainoriené, \\ Natalija Burbulis, \\ Vaida Jonytienè, \\ Aušra Blinstrubienė, \\ Vytautas Rauckis \\ Aleksandro Stulginskio universitetas, \\ Studentu g. 11, LT-53361 \\ Akademija, Kauno r. \\ El.paštasnatalija.burbulis@asu.lt
}

\begin{abstract}
Tyrimai atlikti Aleksandro Stulginskio universiteto Jungtinių tyrimų centro (ASU JTC) Agrobiotechnologijos laboratorijoje. Tirtas kalio hidrokarbonato poveikis fotosintetinių pigmentų, bendrųjų sacharidų ir prolino pokyčiams žaliosios šerytės augaluose užmirkimo sąlygomis. Augalus auginant programuojamoje auginimo kameroje užmirkimo sąlygos buvo sudarytos augalams esant 13 fenologinëje fazèje (pagal BBCH skalę). Nustatyta, kad trumpalaikis drégmès perteklius skatino chlorofilo $a$ ir karotenoidų sintezę, tačiau inhibavo chlorofilo $b$ kaupimąsi žaliosios šerytes augaluose. Ilgiau (72 val.) trunkantis užmirkimo stresas statistiškai patikimai slopino chlorofilo $a$ ir karotenoidų sintezę, o chlorofilo $b$ kiekiui esminès įtakos neturèjo. Purškimas per lapus tirtosiomis kalio hidrokarbonato koncentracijomis skatino fotosintetinių pigmentų sintezę žaliosios šerytės augaluose drègmès pertekliaus sąlygomis. Dèl kalio hidrokarbonato poveikio žaliosios šerytės augaluose nustatyti statistiškai patikimai mažesni prolino ir sacharidų kiekiai, ̨rodantys, kad augalai lengviau adaptavosi prie drègmès pertekliaus streso.
\end{abstract}

Raktažodžiai: fotosintezès pigmentai, kalio hidrokarbonatas, prolinas, sacharidai, užmirkimo sąlygos, žalioji šeryte

\section{IVADAS}

Iš septynių perspektyviausių energetinių žolinių augalų (Zea mays, Sorgum bicolor, Miscanthus giganteus, Panicum virgatum, Andropogon gerardii, Arundo donax, Phalaris arundinacea) penki priskiriami $\mathrm{C}_{4}$ fotosintezès tipo augalų grupei. Skirtingai nei $\mathrm{C}_{3}$ grupès augalai, $\mathrm{C}_{4}$ grupès augalų augimą ir vystymąsi lemiantys veiksniai yra mažiau ištirti, todèl siekiant padidinti energetinių augalų biomasès derlingumą, genetiniai ir fiziologiniai tyrimai tampa vis aktualesni. Minèti energetiniai augalai yra nepatogus objektas in vivo tyrimams dèl didelès biomasès (pvz., drambliažolė užauga iki 2,5-3 m aukščio), todèl tyrimų objektu pasirinktas $\mathrm{C}_{4}$ grupès augalas, turintis mažiausią genomą (apie $510 \mathrm{Mb}$ ) ir trumpiausią gyvenimo ciklą - žalioji šerytė (Doust et al., 2009; Brutnell et al., 2010; Li, Brutnell, 2011).

Augalų fiziologiniai procesai optimaliomis augimo sąlygomis vyksta intensyviausiai. Žemès ūkio sektoriuje dèl įvairių aplinkos stresorių patiriami dideli derliaus nuostoliai, nes sutrinka augalu augimas ir vystymasis (Chaves et al., 2003; Wreford, Adger, 2010). Dèl klimato kaitos poveikio stiprëjant kritulių kiekio svyravimams dažnèja sausros laikotarpiai, tačiau neretai pasitaiko ir trumpalaikès liūtys. Dèl drègmès pertekliaus, dažniausiai po liūčių, sunkesnès granulometrinès sudèties dirvožemiuose dèl intensyvaus dirvų naudojimo dideja dirvožemio suslègimas, prastèja dirbamų dirvų hidrofizikinès savybės, mažèja augalu produktyvumas (Jackson, Colmer, 2005). Net ir trumpai trunkantis dirvožemio užmirkimas daugumai augalų sukelia stresą - augalų šaknys pradeda stokoti deguonies, kuris yra būtinas šaknims; padidèjus $\mathrm{CO}_{2}$ kiekiui šaknyse, sutrinka šaknų vystymasis (Colmer, Voesenek, 2009). Esant stresinems sąlygoms tarp augalo ir aplinkos prastejja dujų apykaita, sutrinka augalų fiziologiniai procesai, energetinis metabolizmas, baltymu apykaita, angliavandenių ịsisavinimas ir kaupimas 
(Bailey-Serres, Voesenek, 2008; Voesenek et al., 2014). Labiausiai dèl užmirkimo augalai nukenčia maksimalaus fotosintezès intensyvumo metu (Armstrong, Drew, 2002). Esant momentiniam stresui, augaluose skatinamas antioksidacinių fermentų, silpninančių oksidacini stresą, aktyvumas (Kacienè, 2014). Taikant atitinkamas auginimo technologijas bei priemones, mažinančias streso poveikị, galima optimizuoti augalų mitybos procesus nepalankiomis agrometeorologinèmis sąlygomis. Kalis - vienas iš makroelementų, dalyvaujančių augalų medžiagų ir energijos apykaitoje, fotosintezeje, kaupiant angliavandenius, palaikant vandens režimą. Kalis augalų ląstelèse randamas $\mathrm{K}^{+}$jonų, ịvairių druskų, iš jų ir kalio hidrokarbonato $\left(\mathrm{KHCO}_{3}\right)$, pavidalu. Kalio hidrokarbonatas yra naudojamas kaip fungicidas, kuris veiksmingas prieš miltligę ir obelų rauples (Wenneker, Kanne, 2010; Marku et al., 2014). Y. C. Li ir J. J. Hao (2013) nustate, kad esant mažai anglies dvideginio koncentracijai aplinkoje $\mathrm{KHCO}_{3}$ skatina baklažanų daigų fotosintezès sistemų efektyvumą.

Tyrimų tikslas - įvertinti žaliosios šerytės atsparumą užmirkimui dèl kalio hidrokarbonato poveikio.

\section{TYRIMŲ METODAI IR SĄLYGOS}

Tyrimai atlikti ASU JTC Agrobiotechnologijos laboratorijoje. I $0,1 \times 0,12 \mathrm{~m}$ vegetacinius indus su substratu išsèta po 50 žaliosios šerytès sèklų. Augalai auginti programuojamoje auginimo kameroje esant $20 / 18{ }^{\circ} \mathrm{C}$ (dieną / naktị) temperatūrai, 16/8 val. (dieną / naktị) fotoperiodui ir $50 \mu \mathrm{mol} \mathrm{m} \mathrm{m}^{-2} \mathrm{~s}^{-1}$ apšviestumui. Užmirkimo sąlygos buvo sudarytos augalams esant 13 fenologinèje fazèje (pagal $\mathrm{BBCH}$ skalę). Tiriamieji augalai nupurkšti $10,20,30 \mathrm{mg} \mathrm{l}^{-1}$ koncentracijų kalio hidrokarbonato tirpalais. Kontrolinio varianto augalai nupurkšti distiliuotu vandeniu. Fotosintezès pigmentų, prolino ir tirpiųjų sacharidų kiekiai nustatyti po 24 ir 72 užmirkimo valandų.

Fotosintetiniai pigmentai: chlorofiluc $a$ ir $b$ bei karotenoidu kiekis lapuose ivertintas pagal D. Wettsteino metodiką (Gavrilenko, Zigalova, 2003) spektrofotometru (100 \% acetono ištraukoje) prie tokių bangos ilgių: chlorofilas $a-622 \mathrm{~nm}$; chlorofilas $b-644 \mathrm{~nm}$; karotenoidai - $440 \mathrm{~nm}$.
Pigmentų koncentracija $\left(\mathrm{mg} \mathrm{l}^{-1}\right)$ skaičiuota pagal formules:

$$
\mathrm{C} a=9,784 \text { D662 - 0,99 D644; }
$$

$\mathrm{C} b=21,426$ D644 - 4,650 D662;

$\mathrm{C} a+\mathrm{C} b=5,134 \mathrm{D} 622+20,436 \mathrm{D} 644$

Ckar $=4,695$ D440,5 - 0,268 $(\mathrm{C} a+\mathrm{C} b)$.

Pigmentų kiekis $\left(\mathrm{mg} \mathrm{g}^{-1}\right)$ apskaičiuotas pagal formulę:

$\mathrm{X}=\mathrm{CV} 100 / \mathrm{n}^{\star} 1000$,

$\mathrm{C}$ - pigmentų koncentracija $\mathrm{mg} \mathrm{l}^{-1}$;

$\mathrm{V}$ - pigmentų ištraukos tūris $\mathrm{ml}$ (ekstrakto kiekis $\mathrm{ml}$ );

$\mathrm{n}$ - analizuojamo bandinio masè.

Prolino kiekis nustatytas taikant modifikuotą ninhydrino metodą (McClinchey, Kott, 2008).

Bendrieji tirpieji sacharidai ivvertinti antrono metodu (Yemm, Willis, 1954). Matavimai atlikti spektrofotometru (Spectro UV-VIS Dual Beam Labomed, Inc).

Tyrimo duomenų statistinè analizė atlikta naudojantis kompiuterinemis programomis iš programu paketo SELEKCIJA (Tarakanovas, Raudonius, 2003).

\section{TYRIMŲ REZULTATAI IR JŲ APTARIMAS}

Abiotinio streso metu gali būti suardytos augalo ląstelès ir susilpnintos jų pagrindinès fiziologinès funkcijos (Larcher, 2003). Dèl drègmès pertekliaus dirvožemyje sutrinka fotosintezès procesas, kurio intensyvumas priklauso nuo fotosintetinančių pigmentų kiekio ir jų santykio augale (Sakalauskiené, 2011), todèl augalu augimas ir vystymasis sulètejja (Zheng et al., 2009).

İvertinus fotosintezès pigmentų kieki po 24 užmirkimo valandų nustatyta, kad dèl drégmès pertekliaus kontroliniai augalai sukaupé daugiau chlorofilo $a$ ir karotenoidų, bet mažiau chlorofilo $b$ (lentelè). Chlorofilo $a$ ir karotenoidų kiekiai padidejjo atitinkamai 0,102 ir $0,054 \mathrm{mg} \mathrm{g}^{-1}$, o chlorofilo $b$ kiekio sumažejjimas - neesminis. Po 72 užmirkimo valandų augaluose statistiškai patikimai sumažéjo karotenoidų ir chlorofilo $a$ - atitinkamai 0,11 ir $0,108 \mathrm{mg} \mathrm{g}^{-1}$, o chlorofilo $b$ kiekis iš esmès nepakito.

Po 24 užmirkimo valandu chlorofilo $a$ ir chlorofilo $b$ santykis ženkliai padidejo, bet po 72 užmirkimo valandų šis rodiklis buvo mažesnis, palyginti su iprastomis drègmès sąlygomis augintais augalais. Priešingai, chlorofilų ir karotenoidų santykis šiek tiek sumažèjo po 24 užmirkimo 
Lentelè. Fotosintetinių pigmentų kiekiai žaliosios šerytės lapuose užmirkimo sąlygomis

Table. The effect of waterlogging conditions on the photosynthetic pigment content in leaves of green foxtail

\begin{tabular}{|c|c|c|c|c|c|}
\hline $\begin{array}{l}\text { Variantai } \\
\text { Variants }\end{array}$ & 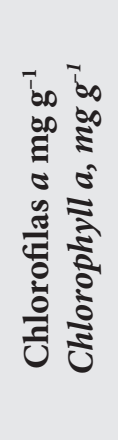 & 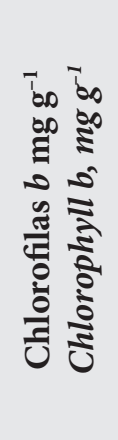 & 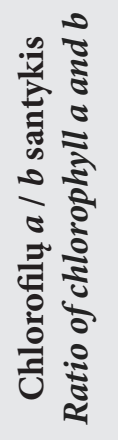 & 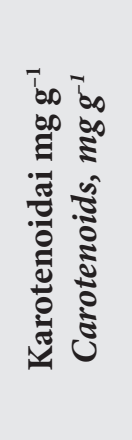 & 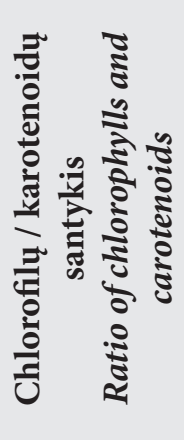 \\
\hline $\begin{array}{l}\text { Iprastos drègmès sąlygos (kontrolè) } \\
\text { Regular moisture content (control) }\end{array}$ & $1,348 b$ & $0,403 a$ & $3,34 b$ & $0,591 b$ & $2,96 \mathrm{~b}$ \\
\hline $\begin{array}{l}\text { Po } 24 \text { užmirkimo valandų } \\
\text { After } 24 \text { hours of waterlogging }\end{array}$ & $1,450 \mathrm{a}$ & $0,398 \mathrm{a}$ & $3,64 \mathrm{a}$ & $0,645 \mathrm{a}$ & $2,87 \mathrm{~b}$ \\
\hline $\begin{array}{l}\text { Po } 72 \text { užmirkimo valandų } \\
\text { After } 72 \text { hours of waterlogging }\end{array}$ & $1,240 \mathrm{c}$ & $0,409 a$ & $3,03 c$ & $0,481 \mathrm{c}$ & $3,43 a$ \\
\hline
\end{tabular}

Pastaba / Note: tarp variantų vidurkių, pažymètų ne ta pačia raide (a,b), skirtumai yra esminiai $(P<0,05)$ / Means not sharing a common letter $(a, b)$ are significantly different $(P<0.05)$.

valandų, bet statistiškai patikimai padidejo po 72 užmirkimo valandų.

Ivertinus tirtujų koncentracijų kalio hidrokarbonato tirpalų poveikị fotosintezès pigmentams nustatyta, kad po 24 užmirkimo valandų daugiausia chlorofilo a sukaupè augalai, nupurkšti $30 \mathrm{mg} \mathrm{l}^{-1}$ kalio hidrokarbonato tirpalu (1 pav.). Po 72 užmirkimo valandų didžiausias chlorofilo $a$ kiekis nustatytas nupurškus augalus $20 \mathrm{mg} \mathrm{l}^{-1}$ kalio hidrokarbonato tirpalu. Be to, dèl šios koncentracijos poveikio

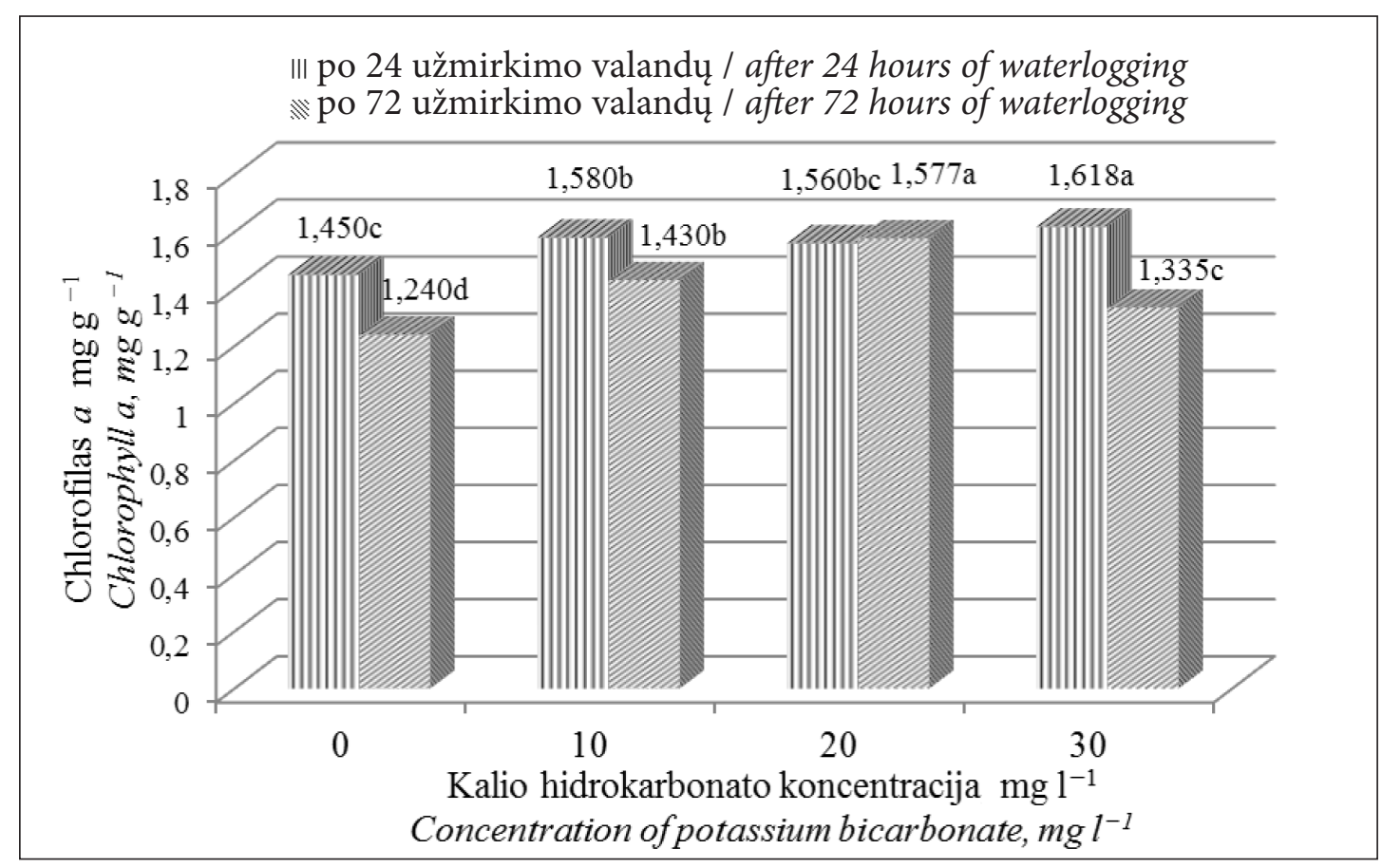

1 pav. Kalio hidrokarbonato poveikis chlorofilo $a$ kiekiui žaliosios šerytės lapuose užmirkimo sąlygomis (tarp variantų vidurkių, pažymètų ne ta pačia raide $(\mathrm{a}, \mathrm{b})$, skirtumai yra esminiai $(P<0,05)$ ) Fig. 1. The effect of potassium bicarbonate on the chlorophyll a in leaves of green foxtail under waterlogging conditions (means not sharing a common letter $(a, b)$ are significantly different $(P<0.05)$ ) 
chlorofilo $a$ kiekis mažai kito, palyginti su augalais po 24 užmirkimo valandų. 10 ir $30 \mathrm{mg} \mathrm{l}^{-1}$ kalio hidrokarbonato koncentracijos taip pat skatino chlorofilo $a$ sintezę, palyginti su kontrole, tačiau jų teigiamas poveikis buvo statistiškai patikimai mažesnis nei $20 \mathrm{mg} \mathrm{l}^{-1}$ koncentracijos.

Analogiškos tendencijos nustatytos ivertinus chlorofilo $b$ pokyčius dèl kalio hidrokarbonato poveikio (2 pav.). Po 24 užmirkimo valandų daugiausia chlorofilo $b$ sukaupé augalai, nupurkšti $30 \mathrm{mg} \mathrm{l}^{-1}$ kalio hidrokarbonato tirpalu. Po 72 užmirkimo valandų didžiausias chlorofilo $b$ kiekis nustatytas nupurškus augalus $20 \mathrm{mg} \mathrm{l}^{-1}$ kalio hidrokarbonato tirpalu. $10 \mathrm{mg} \mathrm{l}^{-1}$ kalio hidrokarbonato tirpalas skatino intensyvesnę chlorofilo $b$ sintezę, o $30 \mathrm{mg} \mathrm{l}^{-1}$ inhibavo šio pigmento kaupimąsi, palyginti su kitomis tirtosiomis koncentracijomis, tačiau statistiškai patikimai didino chlorofilo $b$ kieki, palyginti su kontrole.

Tyrimais nustatyta, kad karotenoidų kiekis žaliosios šerytès augaluose po 24 užmirkimo valandų kito, priklausomai nuo kalio hidrokarbonato koncentracijos (3 pav.). Lyginant su kontrole, statistiškai patikimai daugiau karotenoidų sukaupe augalai, nupurkšti $30 \mathrm{mg} \mathrm{l}^{-1}$ kalio hidrokarbona- to tirpalu. Po 72 užmirkimo valandų daugiausia karotenoidų sukaupė augalai, nupurkšti $20 \mathrm{mg} \mathrm{l}^{-1}$ kalio hidrokarbonato tirpalu. Kitų tirtųjų koncentracijų poveikis buvo statistiškai patikimai mažesnis. Tačiau dèl visų tirtųjų koncentracijų poveikio augalai sukaupé esmingai daugiau karotenoidų nei kontroliniai augalai.

Mokslininkai teigia, kad augalai prisitaiko prie aplinkos stresų keičiant fotosintezès pigmentų kiekius (Alexieva et al., 2003). S. Sakalauskienès (2011) tyrimuose su žirniais nustatyta, kad dèl ultravioletinès B spinduliuotès poveikio mažèjo chlorofilo $a$ kiekis, tačiau aktyvejo chlorofilo $b$ ir karotenoidų kaupimasis. Karotenoidai atlieka svarbią antioksidacinę funkciją - sujungia lipidų peroksidacijos laisvuosius radikalus ir neleidžia chlorofilų molekulėms oksiduotis (Alexieva et al., 2003; Farooq et al., 2009; Jaleel et al., 2009). Mūsų tyrimais nustatyta, kad purškimas per lapus tirtosiomis kalio hidrokarbonato koncentracijomis skatino fotosintetinių pigmentu sintezę žaliosios šerytès augaluose užmirkimo sąlygomis. Didinant tirpalo koncentraciją, chlorofilų ir karotenoidų kiekiai augaluose po 24 užmirkimo valandų nuosekliai didejo. Teigiamas

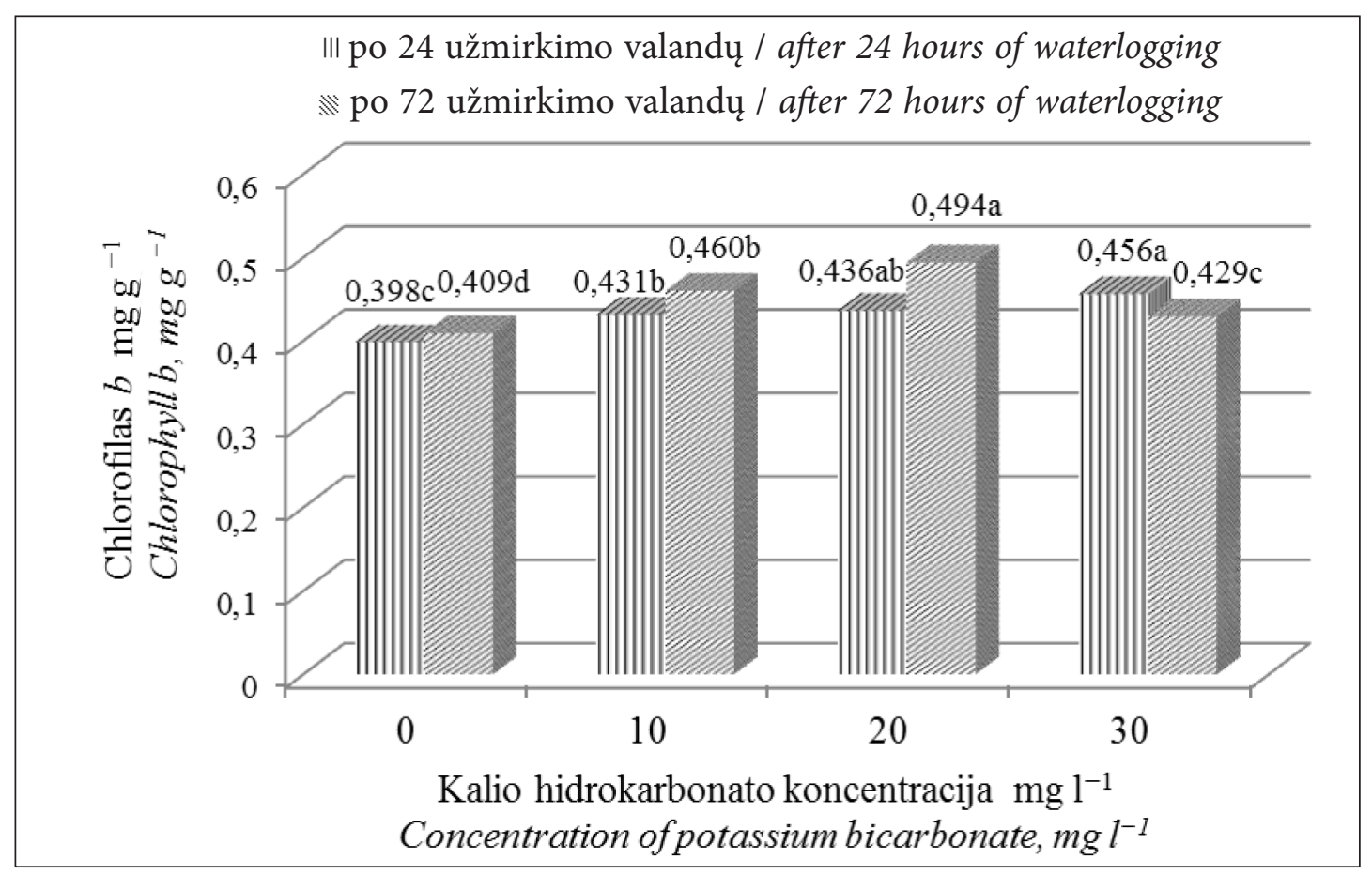

2 pav. Kalio hidrokarbonato poveikis chlorofilo $b$ kiekiui žaliosios šerytės lapuose užmirkimo sąlygomis (tarp variantų vidurkių, pažymėtų ne ta pačia raide $(\mathrm{a}, \mathrm{b})$, skirtumai yra esminiai $(P<0,05))$ Fig. 2. The effect of potassium bicarbonate on the chlorophyll $b$ in leaves of green foxtail under waterlogging conditions (means not sharing a common letter $(a, b)$ are significantly different $(P<0.05)$ ) 


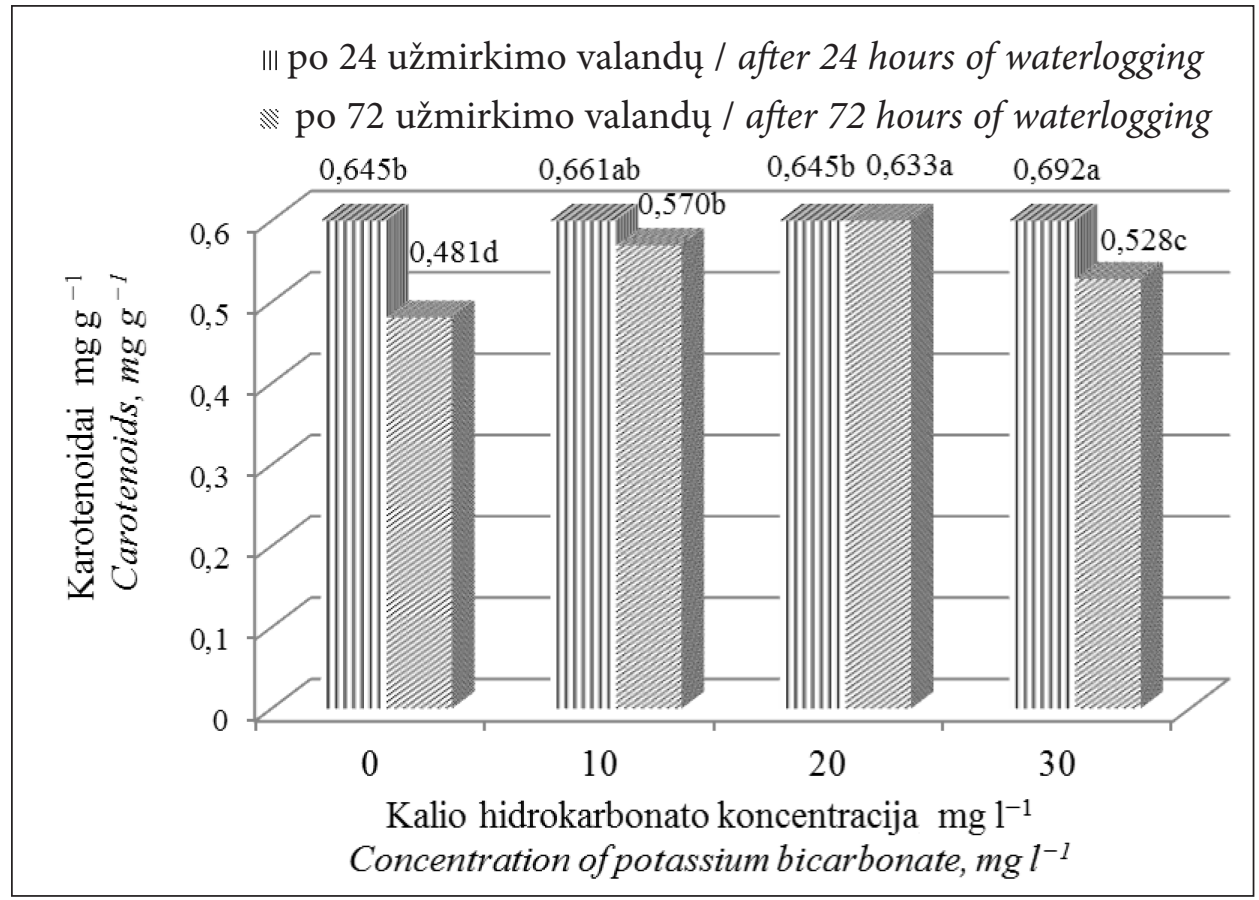

3 pav. Kalio hidrokarbonato poveikis karotenoidų kiekiui žaliosios šerytės lapuose užmirkimo sąlygomis (tarp variantų vidurkių, pažymėtų ne ta pačia raide (a,b), skirtumai yra esminiai $(P<0,05))$

Fig. 3. The effect of potassium bicarbonate on the carotenoids in leaves of green foxtail under waterlogging conditions (means not sharing a common letter $(a, b)$ are significantly different $(P<0.05))$

kalio hidrokarbonato poveikis nustatytas sojų ir ryžių fotosintezès procesui (Yao et al., 2009; Hao et al., 2013).

Nepalankiomis aplinkos sąlygomis augaluose kaupiasi apsauginę funkciją atliekantis prolinas (Patton et al., 2007; Yang et al., 2009; Kumar et al., 2010; Krasensky, Jonak, 2012). Tyrimais irodyta, kad trūkstant drégmés prolinas apsaugo augalo ląsteles nuo dehidratacijos (Parida et al., 2007; Mohammadkhani, Heidari, 2008; Ali et al., 2013). Pagal prolino kiekybinius pokyčius augalu lapuose esant stresui galima spręsti apie augalo fiziologinę būseną.

Aplinkos sąlygos taip pat lemia asimiliantų, iš jų ir sacharidų, judejimą ir pasiskirstymą augale (Wanner, Junttila, 1999; Kaur et al., 2000). Sacharidai yra pirminès medžiagos, reikalingos augalo augimui, vystymuisi bei metabolizmui (Loreti et al., 2001; Kaplan, Guy, 2004). Dèl stresinių veiksnių angliavandeniai aktyvuoja specifinius hormoninių ir nehormoninių signalų perdavimo mechanizmus, lemiančius genų ekspresijos ir fermentų aktyvumo pokyčius (Smeekens, 2000).
Prolino ir sacharidų pokyčiai žaliosios šerytès lapuose užmirkimo sąlygomis pateikti 4 pav. Po 24 ir 72 užmirkimo valandų prolino kiekis padidejo atitinkamai 0,44 ir $2,17 \mu \mathrm{M} \mathrm{g}^{-1}$, palyginti su kontrolinio varianto augalais.

Drègmès perteklius taip pat skatino ir sacharidų kaupimąsi. Lyginant su augalais, augintais iprastomis drègmès sąlygomis, sacharidų kiekis po 24 ir 72 užmirkimo valandų padidejo atitinkamai 1,43 ir 1,66 karto.

Tyrimais nustatyta, kad kalio hidrokarbonatas mažino prolino kiekị žaliosios šerytès augaluose užmirkimo sąlygomis (5 pav.). Nepriklausomai nuo kalio hidrokarbonato koncentracijos, po 24 užmirkimo valandų prolino kiekis statistiškai patikimai sumažèjo.

Po 72 užmirkimo valandų tarp tirtųjų kalio hidrokarbonato koncentracijų išryškejjo esminiai skirtumai - didinant kalio hidrokarbonato koncentraciją prolino kiekis nuosekliai mažejo. Lyginant su kontrole, 10 ir $20 \mathrm{mg} \mathrm{l}^{-1}$ koncentracijomis, šio varianto augalai sukaupe atitinkamai 8,$0 ; 3,6$ ir 1,8 karto mažiau prolino, skirtumai esminiai ir statistiškai patikimi. 


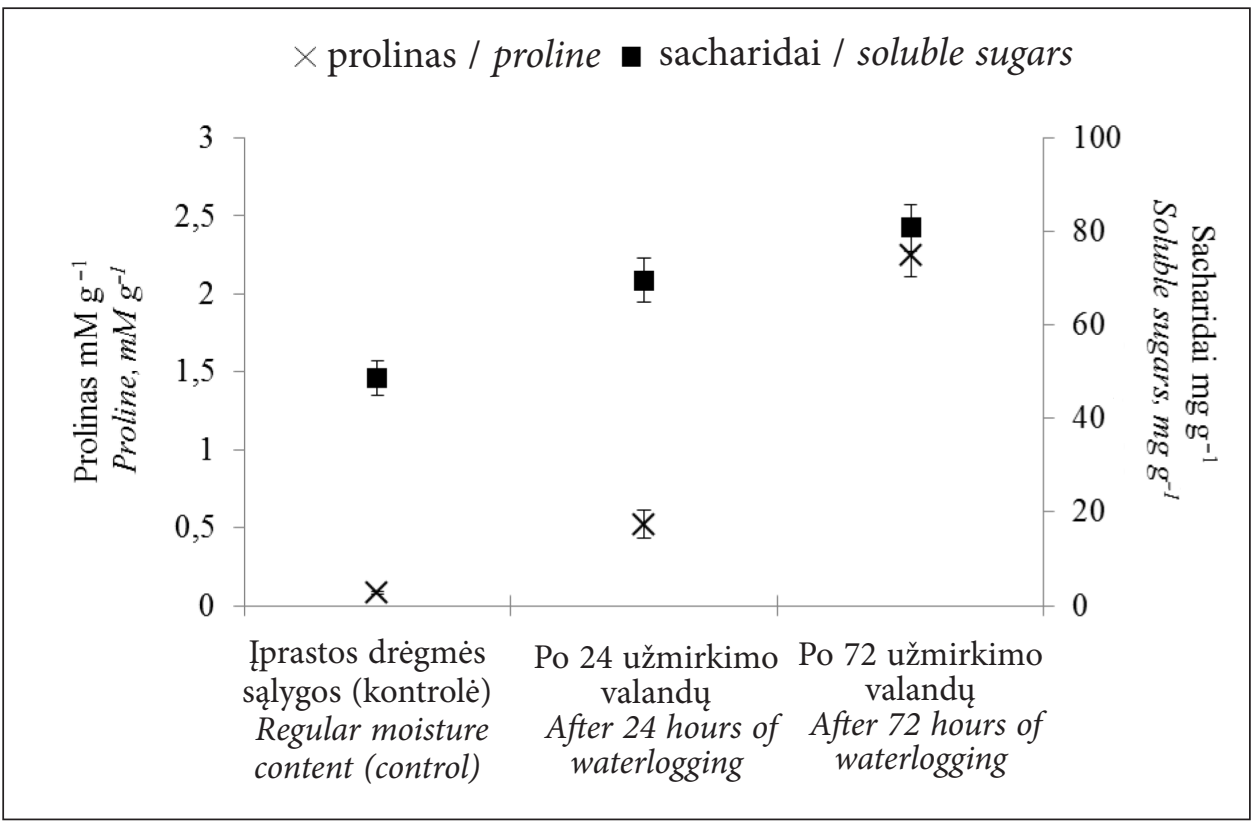

4 pav. Prolino ir sacharidų kiekis žaliosios šerytės lapuose užmirkimo sąlygomis (tarp variantų vidurkių, pažymètų ne ta pačia raide $(\mathrm{a}, \mathrm{b})$, skirtumai yra esminiai $(P<0,05))$

Fig. 4. The effect of waterlogging on the content of proline and soluble sugars in leaves of green foxtail (means not sharing a common letter $(a, b)$ are significantly different $(P<0.05))$

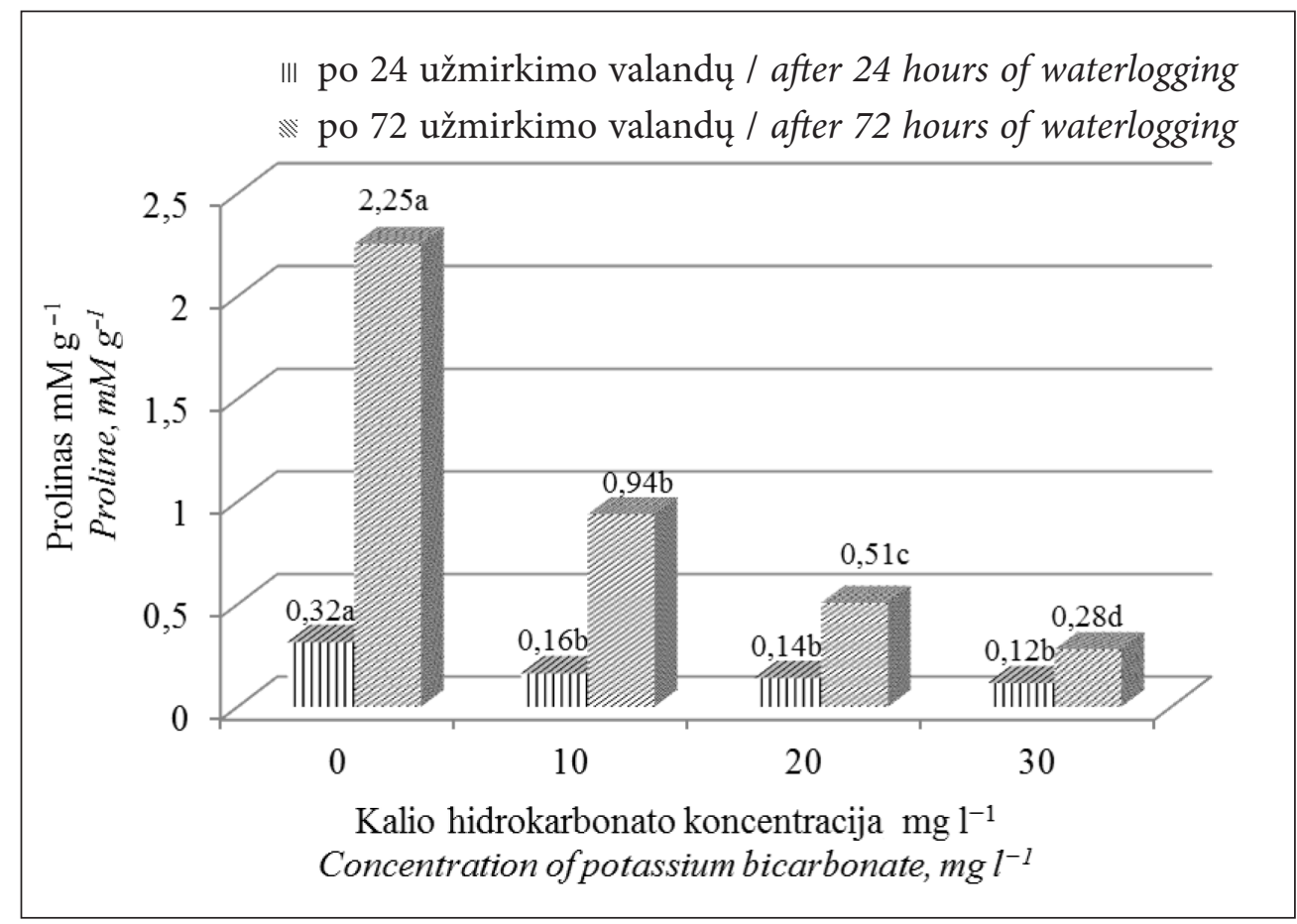

5 pav. Kalio hidrokarbonato poveikis prolino kiekiui žaliosios šerytės lapuose užmirkimo sąlygomis (tarp variantų vidurkių, pažymètų ne ta pačia raide $(a, b)$, skirtumai yra esminiai $(P<0,05))$

Fig. 5. The effect of potassium bicarbonate on the proline content in leaves of green foxtail under waterlogging conditions (means not sharing a common letter $(a, b)$ are significantly different $(P<0.05))$ 


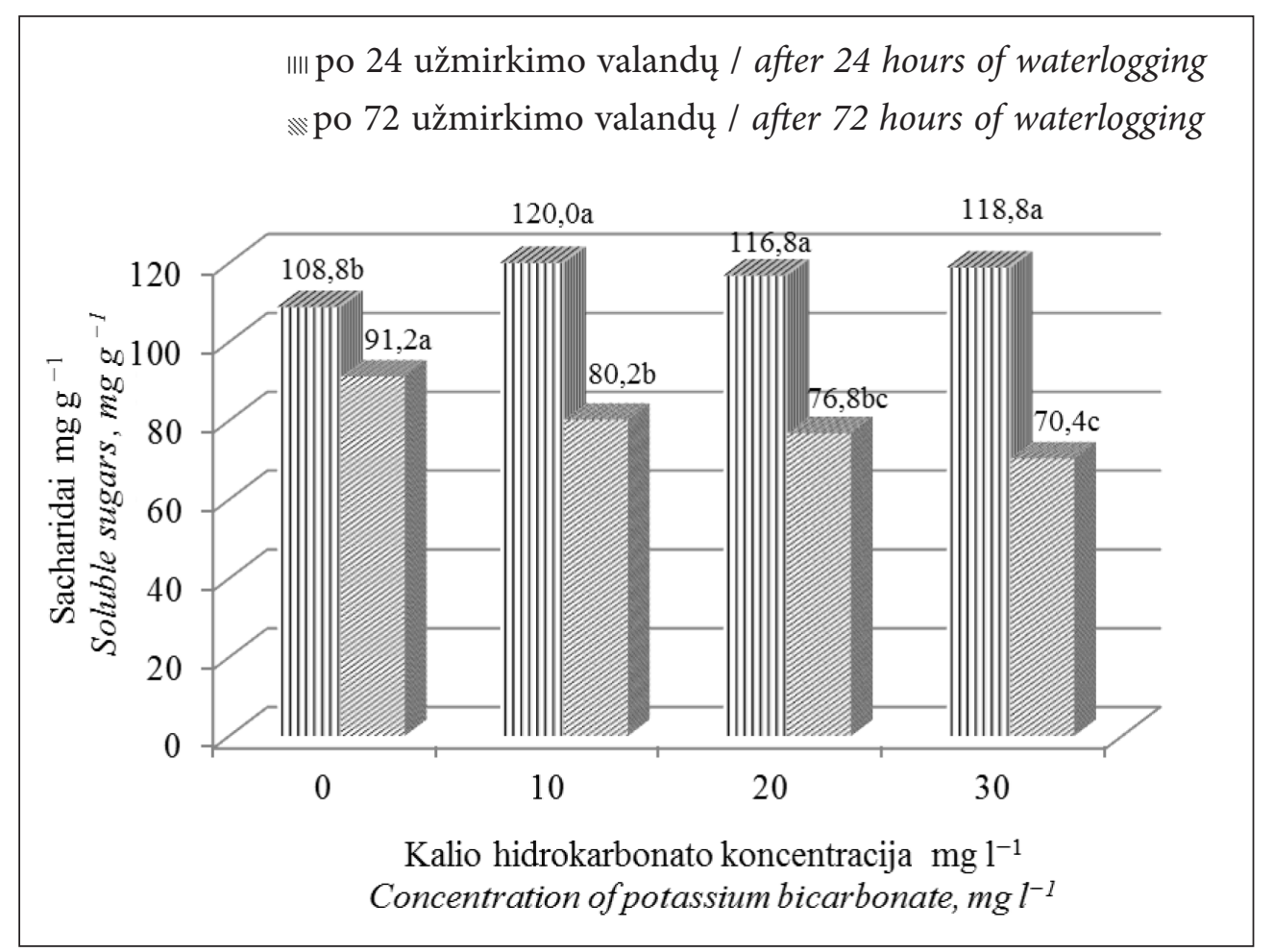

6 pav. Kalio hidrokarbonato poveikis sacharidų kiekiui žaliosios šerytės lapuose užmirkimo sąlygomis (tarp variantų vidurkių, pažymètų ne ta pačia raide $(a, b)$, skirtumai yra esminiai $(P<0,05))$

Fig. 6. The effect of potassium bicarbonate on the content of soluble sugars in leaves of green foxtail under waterlogging conditions (means not sharing a common letter $(a, b)$ are signifcantly different $(P<0.05))$

İvertinus sacharidų kiekị nustatyta, kad po 24 užmirkimo valandų sacharidų kiekis dèl kalio hidrokarbonato poveikio padidejo $8-11,2 \mathrm{mg} \mathrm{g}^{-1}$ (6 pav.).

Po 72 užmirkimo valandų nustatyta, kad didinant kalio hidrokarbonato koncentraciją sacharidų kiekis nuosekliai mažèjo. Lyginant su kontrole, dèl 10; 20 ir $30 \mathrm{mg} \mathrm{l}^{-1}$ kalio hidrokarbonato poveikio sacharidų kiekis sumažèjo atitinkamai 11; 14,4 ir $20,8 \mathrm{mg} \mathrm{g}^{-1}$. Nustatyta, kad sausros stresą patyrę augalai sukaupia didesnius kiekius sacharidų (Krasensky, Jonak, 2012), veikiančių kaip osmolitai palaikant ląstelių turgorą, apsaugant ląstelių membranas ir baltymus nuo streso žalos (Kaplan, Guy, 2004; Mohammadkhani, Heidari, 2008). Padidèjęs sacharidų kiekis augalo lapuose dèl streso slopina fotosintezès veiklą ir lètina augalų augimą (Wang et al., 2010; Sakalauskienè, 2011). Mūsų tyrimais nustatyta, kad tirtosios kalio hidrokarbonato koncentracijos inhibavo sacharidų kaupimąsi žaliosios šerytès augaluose dèl ilgiau trunkančio (72 val.) drègmès pertekliaus.

\section{IŠVADOS}

1. Trumpalaikis drègmès perteklius skatino chlorofilo $a$ ir karotenoidu sintezę, tačiau inhibavo chlorofilo $b$ kaupimąsi žaliosios šerytès augaluose. Ilgiau (72 val.) trunkantis užmirkimo stresas statistiškai patikimai slopino chlorofilo $a$ ir karotenoidų sintezę, o chlorofilo $b$ kiekiui esminès ittakos neturèjo.

2. Purškimas per lapus tirtosiomis kalio hidrokarbonato koncentracijomis skatino fotosintetiniu pigmentų žaliosios šerytès augaluose drègmès pertekliaus sąlygomis.

3. Dèl kalio hidrokarbonato poveikio žaliosios šerytès augaluose nustatyti statistiškai patikimai mažesni prolino ir sacharidų kiekiai, ịrodantys, kad augalai lengviau adaptavosi prie drègmés pertekliaus streso.

Gauta 20160122 Priimta 20160609 


\section{LITERATÜRA}

1. Alexieva V., Ivanov S., Sergiev I., Karanov E. 2003. Interaction between stresses. Bulgarian Journal of Plant Physiology. Special Issue. P. 1-17.

2. Ali Q., Anwar F., Ashraf M., Saari N., Perveen R. 2013. Ameliorating effects of exogenously applied proline on seed composition, seed oil quality and oil antioxidant activity of maize (Zea mays L.) under drought stress. International Journal of Molecular Sciences. Vol. 14. P. 818835.

3. Armstrong W., Drew M. C. 2002. Root growth and metabolism under oxygen deficiency. In: Plant Roots: The Hidden Half. Eds. Y. Waisel, A. Eshel, U. Kafkafi. New York: Marcel Dekker. P. 729-761.

4. Bailey-Serres J., Voesenek L. A. C. J. 2008. Flooding stress: acclimations and genetic diversity. Annual Review of Plant Biology. Vol. 59. P. 313-339.

5. Brutnell T. P., Wang L., Swartwood K., Goldschmidt A., Jackson D., Zhu X.-G., Kellogg E., Van Eck J. 2010. Setaria viridis: a model for $\mathrm{C}_{4}$ photosynthesis. Plant Cell. Vol. 22. No. 8. P. 25372544.

6. Chaves M. M., Maroco J. P., Pereira J. S. 2003. Understanding plant responses to drought - from genes to the whole plant. Functional Plant Biology. Vol. 30. P. 239-264.

7. Colmer T. D., Voesenek L. A. C. J. 2009. Flooding tolerance: suites of plant traits in variable environments. Functional Plant Biology. Vol. 36. P. 665681.

8. Doust A. N., Kellogg E. A., Devos K. M., Bennetzen J. L. 2009. Foxtail millet: a sequencedriven grass model system. Plant Physiology. Vol. 149. P. 137-141.

9. Farooq M., Wahid A., Kobayashi N., Fujita D., Basra S. M. A. 2009. Plant drought stress: effects, mechanisms and management. Agronomy for Sustainable Development. Vol. 29. P. 185-212.

10. Gavrilenko V. F., Zigalova T. V. 2003. Bol'shoy praktikum po fotosintezu. Moskva: Akademiya. $256 \mathrm{~s}$.

11. Ghannoum O. 2009. $C_{4}$ photosynthesis and water stress. Annals of Botany. Vol. 103. P. 635-644.

12. Hao J., Huang Ch., Lu H., Yu Y. 2013. Influence of $\mathrm{K}^{+}, \mathrm{Na}^{+}$and $\mathrm{HCO}_{3}{ }^{-}$on photosynthesis of soybean seedlings. The Global Journal of Science Frontier Research. Vol. 13. No. 3. P. 2249-4626.

13. Yang S. L., Lan S. S., Gong M. 2009. Hydrogen peroxide-induced proline and metabolic pathway of its accumulation in maize seedlings. Journal of Plant Physiology. Vol. 166. P. 1694-1699.

14. Yao L., Yu Y., Hao J. J. 2009. Effects of $\mathrm{KHCO}_{3}$ on photosynthetic rate and growth of rice seedlings. Journal of Shenyang Agricultural University. Vol. 40. No. 6. P. 720-722.
15. Yemm E. W., Willis A. J. 1954. Estimation of carbohydrates in plant extracts by anthore. Biochemistry. Vol. 57. P. 508-514.

16. Jackson M. B., Colmer T. D. 2005. Response and adaptation by plants to flooding stress. Annals of Botany. Vol. 96. P. 501-505.

17. Jaleel C. A., Manivannan P., Wahid A., Farooq M., Somasundaram R., Panneerselvam R. 2009. Drought stress in plants: a review on morphological characteristics and pigments composition. International Journal of Agriculture and Biology. Vol. 11. P. 100-105.

18. Kacienè G. 2014. Skirtingu veiksniu sukeliamas oksidacinis stresas ir jo itaka vasariniu miežiu (Hordeum vulgare L.) atsparumui: daktaro disertacija. Kaunas. 109 p.

19. Kaplan F., Guy C. L. 2004. Beta-amylase induction and the protective role of maltose during temperature shock. Plant Physiology. Vol. 135. P. 16741684.

20. Kaur S., Gupta A. K., Kaur N. 2000. Effect of GA, kinetin and indole acetic acid on carbohydrate metabolism in chickpea seedlings germinating under water stress. Plant Growth Regulation. Vol. 30. P. 61-70.

21. Krasensky J., Jonak C. 2012. Drought, salt, and temperature stress-induced metabolic rearrangements and regulatory networks. Journal of Experimental Botany. Vol. 63. No. 4. P. 1593-1608.

22. Kumar V., Shriram V., Kavi Kishor P. B., Jawali N., Shitole M. G. 2010. Enhanced proline accumulation and salt stress tolerance of transgenic indica rice by over-expressing P5CSF129A gene. Plant Biotechnology Reports. Vol. 4. P. 37-48.

23. Larcher W. 2003. Physiological Plant Ecology. Springer. 513 p.

24. Li Y. C., Hao J. J. 2013. The effect of $\mathrm{KHCO}_{3}$ on photosynthesis of eggplant seedlings. Advanced Materials Research. Vol. 634-638. P. 1129-1134.

25. Li P., Brutnell T. P. 2011. Setaria viridis and Setaria italica, model genetic systems for the panicoid grasses. Journal of Experimental Botany. Vol. 62. No. 9. P. 3031-3037.

26. Loreti E., De Bellis L., Alpi A., Perata P. 2001. Why and how do plant cells sense sugars? Annals of Botany. Vol. 88. P. 803-812.

27. Marku L., Vrapi H., Hasani M. 2014. Effect of potassium bicarbonate (Armicarb) on the control of apple scab (Venturia inequalis) in the region of Puka in Albania. International Refereed Journal of Engineering and Science. Vol. 75. No. 4. P. 563-568.

28. McClinchey S. L., Kott L. S. 2008. Production of mutants with high cold tolerance in spring canola (Brassica napus). Euphytica. Vol. 162. P. 18-27.

29. Mohammadkhani N., Heidari R. 2008. Droughtinduced accumulation of soluble sugars and proline in two maize varieties. World Applied Sciences Journal. Vol. 3. No. 3. P. 448-453. 
30. Parida K. A., Dagaonkar S. V., Phalak S. M., Umalkar V. G., Aurangabadkar P. L. 2007. Alterations in photosynthetic pigments, protein and osmotic components in cotton genotypes subjected to short-term drought stress followed by recovery. Plant Biotechnology. Vol. 1. P. 37-48.

31. Patton A. J., Cunningham S. M., Volenec J. J., Reicher Z. J. 2007. Differences in freeze tolerance of zoysiagrasses: II carbohydrates and proline. Crop Science. Vol. 47. P. 2170-2181.

32. Sakalauskienè S. 2011. Kintančio klimato ir aplinkos veiksniu kompleksinio poveikio žirniu fiziologiniams rodikliams modeliavimas: daktaro disertacija. Kaunas: Akademija. 88 p.

33. Smeekens S. 2000. Sugar-induced signal transduction in plants. Annual Review of Plant Physiology and Plant Molecular Biology. Vol. 51. P. 49-81.

34. Tarakanovas P., Raudonius S. 2003. Agronominiu tyrimy duomenu statistine analize taikant kompiuterines programas ANOVA, STAT, SPLIT-PLOT iš paketo „Selekcija“ ir „Irristat“. Akademija, Kèdainių r. 57 p.

35. Voesenek L. A. C. J., van Veen H., Sasidharan R. 2014. Learning from nature: the use of non-model species to identify novel acclimations to flooding stress. AoB PLANTS. Plant Responses to LowOxygen Environments. Special Issue. P. 1-15.

36. Wang G. P., Li F., Zhang J., Zhao M. R., Hui Z., Wang W. 2010. Overaccumulation of glycine betaine enhances tolerance of the photosynthetic apparatus to drought and heat stress in wheat. Photosynthetica. Vol. 48. No. 1. P. 30-41.

37. Wanner L. A., Junttila O. 1999. Cold-induced freezing tolerance in Arabidopsis. Plant Physiology. Vol. 120. P. 391-400.

38. Wenneker M., Kanne J. 2010. Effect of potassium bicarbonate on the control of powdery mildew (Sphaerotheca mors-uvae) of gooseberry (Ribes uvacrispa). Communication in Agricultural and Applied Biological Sciences. Vol. 75. No. 4. P. 563-568.

39. Wreford A., Adger W. N. 2010. Adaptation in agriculture: historic effects of heat waves and droughts on UK agriculture. International Journal of Agricultural Sustainability. Vol. 8. No. 4. P. 278289.

40. Zheng C., Jiang D., Liu F., Dai T., Jing Q., Cao W. 2009. Effects of salt and waterlogging stresses and their combination on leaf photosynthesis, chloroplast ATP synthesis, and antioxidant capacity in wheat. Plant Science. Vol. 176. P. 575-582.

\section{Rimanta Vainoriené, Natalija Burbulis, Vaida Jonytienè, Aušra Blinstrubienè, Vytautas Rauckis}

\section{THE EFFECT OF POTASSIUM BICARBONATE ON RESISTANCE OF GREEN FOXTAIL TO MOISTURE EXCESS}

Sum mary

Abiotic stresses, which generally inhibit plant growth and development, are responsible for more than $50 \%$ yield loss worldwide. Even short moisture excess conditions can cause stress in many plants. Green foxtail, having the smallest genome and the shortest life cycle, is a very valuable model of plants for in vivo experiments. The study was carried out at the ASU JRC Laboratory of Agrobiotechnology. The effect of potassium bicarbonate on photosynthetic pigments, soluble sugar and proline content in green foxtail under moisture excess conditions was evaluated. Short-time moisture excess stimulated chlorophyll $a$ and carotenoids, but inhibited the accumulation of chlorophyll $b$ in green foxtail plants. Longer (72 hours) excessive moisture stress significantly inhibited chlorophyll $a$ and carotenoids while the amount of chlorophyll $b$ was not significantly influenced. Treatments by tested potassium bicarbonate concentrations stimulated photosynthetic pigment synthesis and ensured a more stable photosynthesis system of green foxtail plants under moisture excess conditions. Potassium bicarbonate significantly decreased proline and soluble sugar contents in green foxtail plants, indicating that plants are more easily adapted to excessive moisture stress.

Keywords: photosynthetic pigments, potassium bicarbonate, proline, soluble sugars, moisture excess conditions, green foxtail 